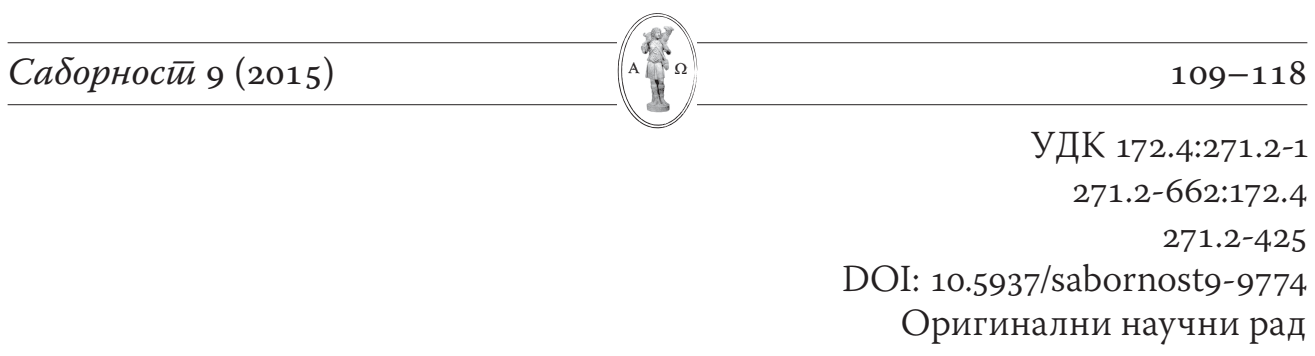

\title{
Ignatije Midić"
}

University of Belgrade, Faculty of Orthodox Theology, Belgrade

\section{Reconciliation in a Socio-political Dimension}

\begin{abstract}
A question we are asking ourselves is the following one: how is peace to be realized and maintained among people? We, as members of the Church, are especially interested to know what the role of the Church is in relation to the problem of realization and maintenance of peace. In order to give positive answers to these questions we need, first of all, to identify what causes hostilities and disturbances to happen among people.
\end{abstract}

Key words: peace, reconciliation, Church, orthodox theology, individualism, rationalism.

$\mathrm{P}$ eace among men and nations represents the very basis of life. Looking from the sociological, economic, political and other aspects, peace is the foundation for survival and existence of every society. Peace and communion among men is the basis for existence also from the aspect of the Church (Cf. Зизијулас, 2013, 2). Anticipating Theophany through the incarnation of the Divine Logos, angels preach "on earth peace, goodwill toward men" (Lk. 2:14). Christ announces that "Blessed are the peacemakers, for they shall be called sons of God" (Mt. 5:9).

Therefore, peace among all humanity is desired by all: socio-political factors and the Church.

A question we are asking ourselves is the following one: how is peace to be realized and maintained among people? We, as members of the Church, are especially interested to know what the role of the Church is in relation to the problem of realization and maintenance of peace. In order to give positive answers to these questions we need, first of all, to identify what causes hostilities and disturbances to happen among people. 


\section{Causes of Disturbances and Wars among Men}

Many causes are usually cited when wars and hostilities among people and nations are being discussed: these are most often observed through national, political, economic and religious differences between the sides involved in conflicts. As a means by which outbreaks of various types of crisis are to be overcome, contemporary civilization strives to eradicate these differences by establishing common economic, political and social systems (Cf. Krstić, 2012). Briefly, the contemporary world strives to integrate social communities on all levels to the degree of advocating common states and religions as a means by which hostilities among people are to be overcome. Disintegration of alliances and the pronounced differentiation among people on all levels, leading to even more open conflicts and bloodier wars, demonstrate the success, or rather failure, of such policies. Whether we are walling or not, this reality forces us, once again, to reconsider the diagnosis offered by the world in relation to the causes of more frequent and ever bloodier conflicts among people, so that we can apply a correct therapy as a cure against this phenomenon, if, of course, we still have enough time and means at our disposal to do so. Therefore, is the cause of conflicts among nations rooted in their different political, social, or religious systems, or should we look for this cause somewhere else?

Contemporary civilization, or the so-called New Age, is marked with conflicts which are without precedent, the bloodiest in history in relation to the number of victims involved, degrees of destruction and the monstrosity of crimes against humanity. As a rule, they can break out either within the same nation (revolutions), or between nations belonging to the same social and economic systems, and, even, between nations confessing the same religion. This means that the source of conflicts among nations is not only to be found in their different economic, political, or religious systems. It seems that there is something in the very roots of contemporary civilization which inevitably leads to conflicts. This is corroborated by the fact that the bloodiest conflicts in most recent history of humankind (e.g. the First and Second World Wars) arose in the bosom of Western Europe, which is the cradle of contemporary civilization, and in those modern states which were established according to models adopted from European civilization: USA, Russia, Japan etc. What then, is the problem with contemporary civilization and where are we to look for sources of all these conflicts? Before we take a look at this problem it is necessary to highlight a very important fact which, as a rule, is usually overlooked in most similar considerations.

There is an essential cause which drives people to separate and distance them from each other, and then to see an enemy in another - this cause is death. Even when we are not completely aware of it, our mortality and the sense of jeopardy which our being registers in relation to death, naturally lead every being, especially a human being, into isolation and create fear of another as a 
precondition to survival. As far as the human person is concerned, his or her relationship to another can be extremely antagonistic, seeing that the human person is the only being on earth which considers his or her jeopardy in relation to death in the perspective of absolute non-existence. People experience death not as a natural occurrence, but as something completely unnatural and in relation to life, which they consider as an eternal process, as a danger and a threat of impending oblivion. Briefly, people tend to justify their hostility towards another from the perspective of self-defense. In a milder form, they see distancing from another as the only precondition to personal prosperity. This state of affairs is known by the Church as the state of the fallen world, because individualism and the tendency to shut out God and the outer world form the very essence of $\sin$. This is why Christianity confesses love and communion with each other and everything around us, not merely as one in a series of Christian values, but as an ontological underlay of life.

However, besides the above mentioned state of affairs, which is present almost since the creation of the world (i.e. since original sin came into effect), there is something else that happened in the world, spawned, it seems, by the contemporary civilization, which caused hostilities among men to turn into world catastrophes of previously unseen proportions. What is it that we are talking about here?

\section{Roots of Contemporary Civilization Stem from Individualism and Rationalism}

The roots of contemporary civilization, which was born in Western Europe, stem from individualism and rationalistic views of the world and of life itself. Starting from St. Augustine ( $5^{\text {th }}$ century AD), who saw man to be an individual carrying the basis of his own identity within himself, through Boetius who defined man as natura individua substantia rationabilis, we saw the foundations of a new (to Christianity), an absolutely foreign ontology - the ontology of individualism - applied to Christian cultures.

Therefore, that which became immanent to every human society since the world began, i.e. individualism and a tendency towards distancing from another, even from God Himself - all of which is seen by Christianity as sin and a projection of false living - became, as far as contemporary civilization is concerned, the only truth - an eternal ontology and the only true state of every human being (Cf. Zizioulas, 2012). A human being's greatness is measured by the extent of his independence in relation to another. The contemporary definition of an individual elaborates on this subject by saying that the human being is measured as an individual and as a person to the extent of his or her own awareness of self and the extent of his or her own awareness of being different and separate from others. 
Based upon this understanding of humanity, and by way of Descartes' philosophy, there later developed rationalism as the basis for life as a whole. The famous maxim of Descartes, cogito ergo sum, implies that logic is the very basis of existence, not only of one who thinks of himself or herself, but also of everything around us.

Such an understanding did not stay in the domain of peripheral individual thought. It became a system branching out to all levels of life and enveloping all spheres of existence. This is best seen by the development of medieval scholastic thought, the purpose of which was, supposedly, to enable the human mind to function properly. Through the appearance of encyclopedists and the establishment of public schools (which were intended to train people to determine what truth is and to learn how to differentiate good from evil, solely by relying upon the power of their minds), this mode of living became the only possible and the only true one. Furthermore, the answer to the question whether God exists or not came to be determined also by this mode of living. The created world was pronounced as the only existing one and was, as such, definitely separated from God. Furthermore, this separation from God became the only mode of the world's very existence, according to this mode and form.

Based on such premises, life as a whole began, little by little, to fragment, and, each of its fragments came to be measured by logic. The world became an object of rational exploration. Truth in the world and the very existence of the world itself are expressed solely by a congregation of many individuals who are not organically connected with one another and, subsequently, the tragedy of one does not signify tragedy for another and vice versa; the existence of one does not necessarily require existence for others. The world is a logical system. It is only necessary to penetrate it and peek at it from the inside. Once we succeed in doing this, then we have the whole world at our disposal and we are able to change it according to our logical requirements and needs. Even if there is something that we cannot logically understand for the time being, that does not mean that this "something" surpasses logic; rather, this would mean that we shall understand it when we reach a higher level of development of our logic. That which logic simply cannot be applied to, e.g. concepts of God and human freedom, is pronounced as unnecessary, non-existent, or irrational. Everything that could not be explained by the power of mind became suspicious and, if not dangerous, then unnecessary.

In such a social context, each person perceives the self in individualistic terms and strives to be secure in relation to others and to be protected against others, which becomes the ultimate goal and the key to personal happiness. Each individual, therefore, uses the mind to search for logical premises of everything perceivable in order to discover how each item is to be used more adequately to achieve one's goals. It is for this reason that the contemporary world considers science and technology as synonyms for the same reality, and 
one cannot operate without the other. All that is immeasurable by logic, by the human mind, and by those instruments constructed by logic in the first place, does not fall into the category of science. Technology is only justified by its purpose. Knowledge is measured solely by its practical value. If our knowledge cannot be put to any use, if it cannot be exploited, then it is equal only to ignorance. The school became everything in such a civilization. It became a church in which the human mind came to be deified, and if the Church did not wish to disappear it had to turn itself into a school.

As a final product of such notions, a point was reached where the human being became sufficient to himself or herself and where his or her happiness was to be built only through the power of the mind. The "other" - the other person and everything else in the world - is there only because it could become an instrument in the process of the attainment of personal happiness. If the other should refuse to oblige, and this based on his or her own mind and logic (finally, the other also has a school diploma!), and thus refuses to become merely an instrument in realization of someone else's notion of happiness, and what is more, expresses a desire to use his or her own "other" as an instrument in attaining his or her own happiness, then "the other" inevitably becomes a foe. In order to reach goals in relation to satisfying certain needs, individuals form groups of peers who, as far as the definition of happiness is concerned, hold similar views, and, if they are more numerous as opposed to other similar groups, their vision of life prevails and becomes a model based upon which the world is to be run. Political parties take part in elections in order to promote their own model of the happy life, and. in the process, take special care to promise happiness to every individual.

This, at a first glance, seems wonderful and seductive (since it seems to offer happiness and freedom to everyone, including the possibility that every individual could, with some luck, one day get a chance to run this world according to his or her own notions and, thus, become absolutely happy). This vision seems so wonderful that almost everyone everywhere, regardless of geographical and cultural variations, desires to adopt this mode of living. Consequently, everyone would be living happily ever after if the resources and sources of wealth, which are necessary components and preconditions to the happiness of contemporary individuals, were not, unfortunately, limited and if they did not need to be shared. Therefore, this kind of personal happiness, or happiness on the national level, inevitably causes calamity or, at best, less happiness for the other. Nationalism is also a product of the age of enlightenment and individualism, and it is not at all by accident that it appeared in the $18^{\text {th }}$ century and that it became the main instigator of most conflicts occurring in Europe and elsewhere in recent years (Сf. Зизијулас, 2012).

This mode of living inevitably leads to confrontations between people and nations which, from time to time, can escalate to hostilities on a broader 
scale, such as world wars. It also instigates great ecological problems which could easily turn into real catastrophes on a worldwide scale. This state of affairs leads some to reassess their inherited convictions, to start doubting the alleged perfection of contemporary civilization, and to start thinking about real causes for wars and other calamities of the $2 \mathrm{O}^{\text {th }}$ century (the $2 \mathrm{O}^{\text {th }}$ century was announced by rationalists and encyclopedists to be the century of heaven on earth, when everyone would be educated; and this, in turn, would cause all evil to disappear from the face of the earth; it is of no little surprise to the world that this century saw some of the bloodiest wars ever). However, there are still a lot of those who put the blame for such conflicts on those nations who have, according to their opinion, remained at a low level of education and development in general, and, if that is not convincing enough, then that blame is put on individuals - supposedly mad people who lead those nations. This implies that many still do not doubt that the contemporary world is perfect.

It is a consequence of individualism and rationalism that Protestantism appeared as a phenomenon, for it is on the basis of individual logic and individual convictions that Protestantism stands in judgment of what is right or wrong and what is needed for salvation within the Church. This was the framework for an unavoidable relativization of everything; not only of morality, in terms of determining what is right and what is wrong, but also in relation to establishing what truth is and what the meaning of existence is. It is a paradoxical, but also an unquestionable fact, which also implies that everything was being determined to the measure of the human mind, that the Roman Catholic Church reacted to Protestantism by introducing dogmas on the pope's infallibility. Again, a single person was to determine what was true and what was false, and all this solely on the basis of his own convictions. Therefore, the Church in the West was forced to reduce itself exclusively to a logically understandable framework, and her actions were reduced only to socially justified and useful activities. Discourses on the topics of faith and dogmas, struggle against the world order as a means of achieving the salvation of the world, as well as acting in such a way as to present and live Church life as an icon of Kingdom of Heaven to come, all but completely disappeared from the list of Church activities. These are all considered not only as unnecessary, but also as non-understandable and even as something to be laughed at - all because they do not stand up to the test of logic.

So, individualism started to reign even within the Church. Seeing and understanding himself of herself as an individual, the human person became distrustful of the other and the collectivity became the arch-enemy which needed to be eradicated at any cost. The human being substituted laws for the Living God and then sacrificed the very same laws for the sake of individualism and infallible opinions. We thus came to a point where we have neither God nor human being who would be holy enough to inspire sacrifice; and all because, 
somewhere along the way, we have lost love. Laws, by themselves, cannot stand up to any single determined attack of rationalism. According to which logic can it be determined what is really good and what is really bad, and why? This question can be heard more and more in this present world of ours. It loudly articulates that which we have only briefly touched upon in so many words.

\section{The Orthodox Church and the Contemporary World}

It is evident that the Orthodox Christianity did not take any considerable part in creating and developing contemporary civilization. This is so because the Orthodox Church, in this period when contemporary civilization was being created, unfortunately, cared little about history. The option for the Kingdom of God, seen as the essence of Christian life, was understood by many as a means to escape the world. It is for this reason that the Church in the East did not make a major contribution in creating many of the problems with which we find contemporary civilization laden, but it is also for the same reason that it did not make any considerable contribution of its own to those new insights which transformed the world, but for the good of the whole world, i.e. in a positive way. However, this does not mean that it does not make use of these new insights and that problems burdening the contemporary world are not its problems also. The modern world, as we know it, is a legacy of both the West and the East (Cf. Krstić 2014). Specifically, individualism and rationalism, and convictions based upon them which proclaim self-sufficiency of one person and one nation in relation to another, are ever more present in all spheres of life, even in traditionally Orthodox countries, which also include many aspects of both social and Church life in those countries. The recent bloody conflicts in the Balkans, Europe and elsewhere offer a good enough proof for such a conclusion. It is an ever more frequent occurrence within the Orthodox Church that, based upon the contemporary model of living and our attitude to our surroundings, even the Church tradition is being used as a means for taking distance from others, both on the level of East-West relations, and also on the level of relations within the Church itself. Frequently both in the East and the West, Church identity is being understood not in relation to communion and love of one another, but, rather, in relation to distancing of one from the other and, God forbid, in relation to hatred towards the other for the sake of and in the name of God!

That which the Orthodox Church has saved through its tradition and which it could offer to the world as a means of salvation, also in relation to the question of conflicts between people and nations, and without pretending to profess establishment of Heaven on earth (as it was attempted in the West) before the universal cancellation of death and the second and glorious coming of Christ, is its teaching of God Who is the Holy Trinity - communion of Persons. Based on this teaching come both the structure and the very existence of the Church. 
The great Christian truth which, even if only partly, transfigured the world and history in relation to the pre-Christian period, is the revealed truth that God, as One Being and as the Model for every existence, is the Holy Trinity. God is the communion of Persons of Father, Son and the Holy Spirit. There is no God other than the Holy Trinity. However, each Person is eternal and unique - an absolute and free Being in communion of freedom and love with the other Person. The Father is an absolute Person and the Source of Godhead because He has Son and the Holy Spirit in eternity. The Son and the Holy Spirit are in a state of eternal communion with the Father, Who is the Source of Their eternal absolute identity. This is why God is love, because He is the eternal communion of Persons.

On the practical, living plan of the Church in history and throughout ages, this Mystery of God's existence is reflected in its expression through Liturgical communion. Orthodox Liturgy, being a synonym for the Church itself, is a communion of all faithful living in one place under one bishop, and this not based upon their nationality, color of their skin, sex or age, but based upon their freedom and love of one another. This communion is shared by all creation, material and spiritual world, plants and animals, so that it can transfigure itself and become eternal - everything is included in this but sin; and sin is nothing but separation of oneself from others and the breaking of communion, that is the lack of mutual love, and exploitation of another and the world as a means to satisfy personal lust. Realization of love towards another and towards all creation is the very basis of Christian asceticism, an experience more preserved in Eastern Christianity - than in the West. This ascetic experience teaches and trains us to love the other regardless of any differences between us and, in doing so, to understand what it really is to be a person and a unique being in relation to another, i.e. leads us into Liturgical communion which is the Church. For only unselfish and sacrificial love of another can reveal not only the absolute importance of another in relation to our own existence, but also the great mystery of God's existence as a Holy Trinity, as well as the redemptive state of communion of us in Her through Christ.

Therefore, Orthodox Liturgy, being the very icon of God and God's existence, should serve as a model towards establishing and maintaining world order (Сf. Мидич, 2013).

By way of a conclusion, and based on my modest opinions, this short deliberation was meant to point out one of the important causes of conflicts and wars between nations here in the Balkans, in Europe as a whole, and on a worldwide scale. Individualism and rationalism employed as modes of living dangerously divide the one, unique and indivisible world of God, even to the extent of its destruction. World wars, as well as the most recent Balkan conflicts, and worldwide conflicts in general, have allowed us to get a glimpse of a possible catastrophe which might befall us all if we do not seriously reconsider 
our present ways of living. Those ways are characterized by dangerous divisions, both in the world as a whole, and in the spheres of Church life itself. Even more tragic is the fact that there is a tendency, both in the East and the West, to allow this divisiveness to become the very foundation of true existence, and to pronounce it to be the greatest value. I personally hope and pray to the Lord, Whose wish it is for us all to become one that Christianity will, after all, save the world with love and unity.

\section{References}

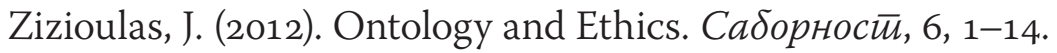

Зизијулас, J. (2013). Истина, толеранција, монотеизам. Да ли је могућ један међурелигијски дијалог?. Саборнос $\bar{u}, 7,1-5$.

Krstić, Z. (2012). Impact of the Economical Crisis on the Social Structure of

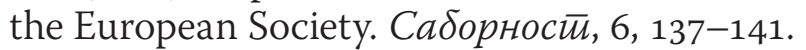

Крстић, 3. (2014). Могућности хришћанског теолошког мишљења у постмодерности. Саборносй, 8, 17-26.

Мидич, И. (2013). Православное богословие сегодня - Проблемы и пер-

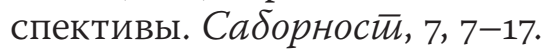




\section{Игнатије Мидић}

Универзитет у Београду, Православни богословски факултет, Београд

\section{Помирење - социјално-политичке димензије}

$\Pi$

итање које постављамо је следеће: како остварити и очувати мир међу људима? Посебно нас, припаднике Цркве, интересује која је улога Цркве у остварењу и очувању мира? Да бисмо могли позитивно да одговоримо на ова питања, потребно је најпре пронаћи узрок непријатељствима и немирима међу људима.

Key words: мир, помирење, Црква, православна теологија, индивидуализам, рационализам.

Датум пријема чланка: 18. 6. 2015.

Датум прихватања чланка за објављивање: 17. 12. 2015. 